\title{
Decreased Cellularity Present
}

National Cancer Institute

\section{Source}

National Cancer Institute. Decreased Cellularity Present. NCI Thesaurus. Code C139138.

A decrease in the number of cells as compared to a standard or norm. 